\title{
MATHEMATICAL MODELING OF AN INTEGRATED MEMBRANE REACTOR FOR METHANE STEAM REFORMING
}

\author{
Grazia Leonzio 1 \\ ${ }^{1}$ Department of Industrial and Information Engineering and Economics, University of L'Aquila, Via Giovanni Gronchi \\ 18, 67100 L'Aquila, Italy
}

\begin{abstract}
Today methane steam reforming is the primary way to produce hydrogen, due to the abundant availability of natural gas and its economic benefits respect to other processes. Higher purity of hydrogen can be obtained with membrane reactor. In this research a mathematical modeling for methane steam reforming reaction operating in steady state is developed for an integrated membrane reactor. A one-dimensional, pseudo-homogeneous model in isothermal mode is used. Ni(10)/CeLaZr catalyst supported on SSiC ceramic foam is used to ensure a better temperature distribution inside the reactor respect to a common pellet catalyst. Acceptable results are obtained with Numaguci kinetic and not with the common Xu and Froment kinetic that is very fast. A sensitivity analysis is carried out to study the effect of temperature and pressure on methane and carbon dioxide conversion and hydrogen yield: both parameters have a positive effect on the responses. Experimental tests are carried out to measure pressure drops inside the foam sample according the Hazen-Dupuit-Darcy equation: value of permeability and drag coefficient are obtained and are equal to $0.00043 \mathrm{~m}^{2}$ and $0.04029 \mathrm{~s}^{2} / \mathrm{m}$ respectively. An isotropy test shows that this property is not present for the studied foam. In this case, the value of permeability and drag coefficient are equal to $4.59 \cdot 10^{-5} \mathrm{~m}^{2}$ and $0.07 \mathrm{~s}^{2} / \mathrm{m}$ respectively.
\end{abstract}

Keywords: Methane Steam Reforming, Integrated Membrane Reactor, Kinetic Reaction, Mathematical Model, Pressure Drops, Hydrogen Production.

\section{INTRODUCTION}

Today the extensive resources of natural gas available over the world recommend the methane steam reforming as the most promising and economically most feasible solution for hydrogen production. Hydrogen is a green energy carrier and can supply the energy demand in an environmentally way using the best developed technologies. As the 21's century energy, it is the main fuel used in processes for the production of ammonia, methanol and in the Fischer Tropsch synthesis [1].

Globally, about 50 million tons of hydrogen are annually produced via methane steam reforming. Other methods of hydrogen production are from renewable sources: biomass or electrolysis of water at high temperature using solar energy. Also, renewable feed-stokes as bio-ethanol can be used in the future [2].

Membrane reactors are used to produce hydrogen at high purity in compact systems, in the last years. A membrane react or can do simultaneously a reaction (steam reforming, dry reforming, auto-thermal reforming, etc.) and a separation through the membrane, that plays the role of a separator, but also takes place in the reaction itself. So conversion and selectivity of the reaction are improved, avoiding the use of other traditional systems as pressure swing adsorption or cryogenic separation. In literature, there are several examples about membrane reactors for hydrogenation and dehydrogenation $[3,4,5,6]$, methane steam reforming [7, 8] and water-gas shift [9] to produce hydrogen. In general, tubular reactors filled using nickel as catalyst, at temperatures above $850{ }^{\circ} \mathrm{C}$, pressure between 3 atm and 25 atm and steam to methane feed flow ratio between 2 and 4 are traditionally used [10]. Membrane reactors have several advantages: reduced capital and downstream separation costs (the separation is integrated), improved yields, selectivities (due to the equilibrium shift) and mass transfer. Several patents about membrane reactors are reported by Deckman et al. [11], Sufang et al. [12], Mei et al. [13], Morico et al. [14]. Other works that are present in literature study the influence of operating conditions such as temperature, reaction pressure, sweep flow rate and steam to carbon ratio $(\mathrm{S} / \mathrm{C})$ on conversion, $\mathrm{H}_{2}$ production rate and $\mathrm{CO}_{2}$ in the feed $[15,16,17]$. Researches are studying the configuration of the membrane reactor that can improve the efficiency of the process. De Falco et al. [18] study experimentally different configurations of the reactor with embedded or external membrane involved in the reforming process. In addition, a separated reformer-Pd membrane module, called "open architecture" is developed by Borgognoni et al. [19]. In other configurations, solar heated molten salts are used as an external source of thermal energy, improving the sustainability and the thermal efficiency of the system: the necessary heat to maintain the chemical reaction is supplied and the carbon footprint is decreased [20, 21]. The use of membranes allows to work at very low temperatures and pressures and to have higher conversions [7, 22]. Infect, the methane steam reforming reaction for hydrogen production is limited by thermodynamic equilibrium: the reactions take place at high temperatures $\left(>800{ }^{\circ} \mathrm{C}\right)$ to have high methane conversion 
and hydrogen yield. However, in membrane reactors higher methane conversion can be obtained at lower temperatures, less than $550{ }^{\circ} \mathrm{C}$ : the selective removal of hydrogen from reaction place through membranes allows to overcome the thermodynamic equilibrium limitation. A sweep gas, commonly a stream of $\mathrm{H}_{2} \mathrm{O}, \mathrm{N}_{2}, \mathrm{He}$ or $\mathrm{O}_{2}$, is generally used to subtract hydrogen from reaction zone and produce a hydrogen stream with concentration of $\mathrm{CO}$ and $\mathrm{CO}_{2}$ significantly lower [23, 24]. Different type of materials can be used for membranes: polymeric membranes, porous membranes, dense metal membranes and proton conducting membranes (dense and composite ceramic membranes).

Dense metal and ceramic membranes have high hydrogen selectivity so they can produce a permeate stream with hydrogen at high purity. Also, micro-porous ceramic membranes(crystalline and amorphous) are promising materials, but the selectivity is still limited compared to the more expensive dense inorganic membranes because they separate hydrogen by size exclusion. Pd-alloys (mainly Pd$\mathrm{Ag}, \mathrm{Pd}-\mathrm{Cu}$ and $\mathrm{Pd}-\mathrm{X}-\mathrm{Au})$ are used to decrease the embrittlement problem and the poisoning of membranes generating by the contact with $\mathrm{H}_{2} \mathrm{~S}, \mathrm{CO}$ and other pollutants $[25,26]$. Experimental studies and DFT-based calculations how that Pd in binary or ternary alloys improves the permeability of the membranes[27, 28]. In particular, Au or Ag can increase the permeability of the alloy of up to 5 times respect to $\mathrm{Ni}, \mathrm{Rh}, \mathrm{Pt}$ [29]. The hydrogen permeates selectively a wall of membrane accordingly to the Sieverts' law. In order to improve the selectivity, composite membranes with thin metal films, coated over a porous support via electrolysis plating or sputtering are also used [30]: the hydrogen permeability and selectivity depend by the coverage of the support pores. In the steam reforming reaction, different catalyst can be used: noble metals, such as $\mathrm{Pt}, \mathrm{Pd}$ and $\mathrm{Rh}$, and non-noble metals, such as $\mathrm{Co}, \mathrm{Ni}$ [31, 32, 33, 34].Ni-based catalysts have been historically used primarily due to their low costs. However, a more active catalyst, such as $\mathrm{Ru}$ can maximize the performance of a membrane reactor $[35,36]$. In general, pellet supports are used but show low thermal dispersion due to its low thermal conductivity: cold or hot spots are produced on the catalyst surface during reforming, particularly as the reformer scale is increased. Hot spots can damage the catalyst while cold spots can decrease the catalytic activity, so an uniform temperature distribution through the reaction is very important. Recently, metallic and ceramic foam catalysts (a porous metal inside which many pores are formed) with high thermal conductivity, uniform thermal dispersion and high mechanical strength have been studied widely. Foams are classified into two types: open and closed cells [37, 38]. The closed cell-type foam has pores that are not interconnected, whereas the open cell type metallic foam has pores that are interconnected: a fluid can pass easily through the metallic foam. The open cell-type metallic foam is used widely in a range of industrial fields. The metallic foam can improve the catalytic activity due to its high specific surface area, can improve the heat and mass transfer and can minimize the pressure drops due to its porous structure [39, 40]. The ceramic foam due to the high mechanical strength and thermal conductivity [41, 42], are used as catalyst supportin reactors that use solar energy [43, 44, 45]. Metallic foams as $\mathrm{Cu}$, have better thermal conductivity and are less breakable compared to ceramic foams: the use of metallic foams is growing [32, 46]. In general, recent researches focus the attention to develop catalysts that produce minimum $\mathrm{CO}$ content with outing hydrogen production.

Mathematical modeling of membrane reactor is an active area of research in developing: there are significant amount of works that can be used as an effective tool for the design, evaluation and optimization of the process. There are isothermal [47, 48] e non isothermal [49, 50, 51, 52] modeling. Isothermal operation is generally assumed, but there are few other works that use also energy balances, simulating the non-isothermal operation [7, 53]. However, the existing models are one dimensional, so they are not capable to describe the heat and mass transfer processes inside the reactor $[50,54,55,56,57,58,59]$. In addition, this kind of model, are not able to study the influence of the structural and textural properties of membrane on the system[60]. Membrane reactors show radial concentration and temperature gradients, due to the mass and heat transfer through the membrane, so bi-dimensional models are more accurate $[61,62,63,64,65]$. Tri-dimensional models are the most complex and are used only for highly nonsymmetrical reactors [66]. Optimization purpose of this models is underlined by Simakov and Sheintuch [58], De Falco [20], Caravella et al. [67], Oyama and Hacarlioglu [68]. Several authors are developed mathematical models at various levels of complexity underlining the advantages of membrane reactors: mostly are at steady-state condition and onedimensional $[4,53,57]$ and few works are at steady-state condition and two-dimensional [69].

From literature analysis can be deducted that the extended and systematic studies of membrane reactors for methane steam reforming in the last two decades aims at abolishing the limited understanding of the membrane reactor behavior and facilitating its industrial implementation. In this condition the study of membrane reactors at pilot scale is necessary. In general, at an industrial scale methane steam reforming reaction operates over Ni-based catalyst pellets in tubular reactors. The use of Ni-based supported foam is not meticulously investigated and no profound studies on modeling reforming reactions over foams exist [70]. Moreover, the lack of profound understanding of large-scale membrane reactors and their behavior hinders the implementation of novel membrane reactor strategies and is therefore attractive to study. To this purpose a mathematical modeling of integrated membrane reactor for methane steam reforming is carried out in this paper. It is the first integrated membrane reactor at pilot plant in Europe that uses $\mathrm{Ni}(10) / \mathrm{CeLaZr}$ catalyst supported on $\mathrm{SSiC}$ ceramic foam. Material balances of carbon dioxide and methane and the permeation of hydrogen through membrane are solved with Matlab software (using the Runge and Kutta algorithm). Results show that the used of $\mathrm{Xu}$ and Froment kinetic [71] is not suitable to describe the system, being too fast. Acceptable results are obtained using the Numaguchi kinetic. So a new kinetic is used to describe the methane 
steam reforming reaction inside the integrated membrane reactor and at pilot plant. A sensitivity analysis is carried out for a better understanding of the process, analyzing the effect of temperature and pressure on methane and carbon dioxide conversion and the effect of temperature and pressure on hydrogen yield. Experimental analysis of pressure drops are used to develop a mathematical model according the Hazen-Dupuit-Darcy equation, funding the values of permeability and drag coefficient.

\section{MATERIALS AND METHODS}

\section{1description of the Integrated Membrane Reactor}

\section{and Catalyst}

Fig. 1 shows the configuration of the integrated membrane reactor that consists of an external steel tube (shell) with an inner membrane wall tube where sweep gas (steam) flows to drag the permeate hydrogen.

The selective membrane allows to obtain hydrogen with high purityand to improve the conversion of the reaction, despite the lower operating temperatures. Methane and steam are continuously feeded: the molar ratio of steam to carbon $(\mathrm{S} / \mathrm{C})$ is equal to $1: 3$, the maximum temperature is $550{ }^{\circ} \mathrm{C}$ and the maximum pressure of 10 atm over a $\mathrm{Ni}(10) / \mathrm{CeLaZr}$ catalyst supported on SSiC ceramic foam.

The flexibility on providing heat is externally ensured by utilizing solar energy and molten salts, as the binary mixture of $\mathrm{NaNO}_{3} / \mathrm{KNO}_{3}(60 / 40 \% \mathrm{w} / \mathrm{w})$ called "solar salts". This heat transfer fluid has low cost, allowing mismatch between the fluctuating solar source and the operation of the chemical plant.

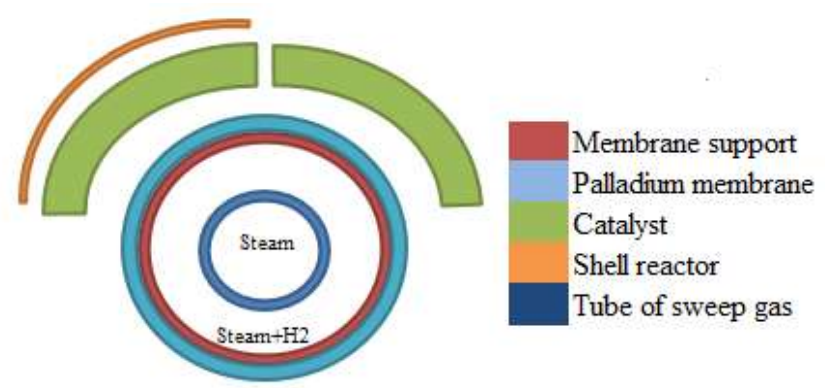

Fig-1: Section of the integrated membrane reactor

Table 1: Dimensions of the integrated membrane reactor

\begin{tabular}{|l|c|c|}
\hline & $\begin{array}{c}\text { Internal } \\
\text { diameter } \\
(\mathrm{mm})\end{array}$ & $\begin{array}{c}\text { External } \\
\text { diameter }(\mathrm{mm})\end{array}$ \\
\hline Membrane support & 10 & 14 \\
\hline Palladium membrane & n.a. & n.a. \\
\hline Catalyst & 16 & 40 \\
\hline Shell reactor & 42.7 & 48.3 \\
\hline Tube of sweep gas & 6 & 9 \\
\hline
\end{tabular}

A pseudo-homogeneous, one-dimensional and isothermal model is developed to simulate the performance of the integrated membrane reactor. The main assumptions of the models are the following: stationary condition, cylindrical symmetry, catalytic bed in isothermal conditions, onedimension model, modeling of pseudo-homogeneous catalytic bed with mechanical, thermal and kinetic equivalence to a granular bed, the polarization phenomena for concentration is not considered, the inhibition phenomena due to the impurities are negligible, co-current flow mode. The assumption of the isothermal operation is guaranteed by the use of molten salts. Infect, the assumption of isothermal operation in a reactor is related to the higher reaction heat respect to the heat loss/gain through the reactor walls. According to this, for the reactor of this research, ahigh ratio between heat transfer area and reaction volume is present, respecting the first consideration. However, this condition may not be true whit higher process scales [53].

\subsection{XU and Froment Kinetic Reaction According to}

\section{the Langmuir-Hinshelwood Model}

Methane steam reforming consists in two endothermic reactions and the exothermic water-gas swift reaction according the following scheme (See eq. 1-3):

$$
\begin{aligned}
& \mathrm{CH}_{4}+\mathrm{H}_{2} \mathrm{O} \leftrightarrow \mathrm{CO}+3 \cdot \mathrm{H}_{2} \\
& \mathrm{CO}+\mathrm{H}_{2} \mathrm{O} \leftrightarrow \mathrm{CO}_{2}+\mathrm{H}_{2} \\
& \mathrm{CH}_{4}+2 \cdot \mathrm{H}_{2} \mathrm{O} \leftrightarrow \mathrm{CO}_{2}+4 \cdot \mathrm{H}_{2}
\end{aligned}
$$

The reaction enthalpy is respectively equal to $206,-41,165$ $\mathrm{kJ} / \mathrm{mol}$ and the overall products are $\mathrm{CO}, \mathrm{CO}_{2}$ and $\mathrm{H}_{2}$. The third reaction is a linear combination of the other reactions. The mathematical model of the kinetic follows the Langmuir-Hinshelwood mechanism according to $\mathrm{Xu}$ and Froment [71]. The rates of reactions are (See eq. 4-7):

$$
\begin{aligned}
& r_{1}=\frac{\frac{k_{1}}{P_{H 2}^{2.5}} \cdot\left(P_{C H 4} \cdot P_{H 2 O}-\frac{P_{H 2}^{3} \cdot P_{C O}}{K_{1}}\right)}{D E N^{2}} \\
& r_{2}=\frac{\frac{k_{2}}{P_{H 2}} \cdot\left(P_{C H 4} \cdot P_{H 2}-\frac{P_{H 2} \cdot P_{C O}}{K_{2}}\right)}{D E N^{2}} \\
& r_{3}=\frac{\frac{k_{3}}{P_{H 2}^{3.5} \cdot\left(P_{C H 4} \cdot P_{H 2 O}^{2}-\frac{P_{H 2}^{4} \cdot P_{C O 2}}{K_{3}}\right)}}{D E N^{2}}
\end{aligned}
$$

$D E N$

$=\frac{1+K_{C O} \cdot P_{C O}+K_{H 2} \cdot P_{H 2}+K_{C H 4} \cdot P_{C H 4}+K_{H 2 O} \cdot P_{H 2 O}}{H_{2}}$

where $r_{j}(j=1-3)$ are the reaction rates, $k_{j}$ are the reaction constants according Arrhenius relation $\mathrm{k}_{\mathrm{j}}=\mathrm{k}_{\mathrm{j}}^{0} \exp \left(-\mathrm{E}_{\mathrm{j}} / \mathrm{R} \cdot \mathrm{T}\right)$, $\mathrm{K}_{\mathrm{i}}\left(\mathrm{i}=\mathrm{CH}_{4}, \mathrm{H}_{2} \mathrm{O}, \mathrm{H}_{2}, \mathrm{CO}\right)$ are the adsorption constants expressed as $\mathrm{Ki}=\mathrm{K}_{\mathrm{i}}^{0} \exp \left(-\Delta \mathrm{H}_{\mathrm{i}} / \mathrm{R} \cdot \mathrm{T}\right)$. In the system reaction, only the first and second reactions are linearly independent: the expressions for methane and carbon dioxide conversion are the following (See eq. 8-9): 


$$
\begin{aligned}
X_{\mathrm{CH} 4} & =\frac{F_{C H 4}^{o}-F_{C H 4}}{F_{C H 4}^{o}} \\
X_{\mathrm{CO} 2} & =\frac{F_{C O 2}^{o}-F_{C O 2}}{F_{C O 2}^{o}}
\end{aligned}
$$

where $\mathrm{X}_{\mathrm{CH} 4}$ and $\mathrm{X}_{\mathrm{CO} 2}$ are the methane and carbon dioxide conversion respectively, $\mathrm{F}_{\mathrm{CO} 2}$ and $\mathrm{F}_{\mathrm{CH} 4}$ the flow rate of carbon dioxide and methane respectively, $\mathrm{F}^{\circ}{ }_{\mathrm{CH} 4}$ and $\mathrm{F}_{\mathrm{CO} 2}^{\circ}$ respectively the initial methane and carbon dioxide flow rate. The expressions for partial pressures of components are a function of the conversions (See eq. 10-16):

$$
\begin{aligned}
& P_{C H 4}=\frac{\left(1-X_{C H 4}\right)}{\sigma} \\
& P_{C O}=\frac{\left(\theta_{C O}-X_{C O 2}+X_{C H 4}\right)}{\sigma} \\
& P_{C O 2}=\frac{\left(\theta_{C O 2}+X_{C O 2}\right)}{\sigma} \\
& P_{H 2 O}=\frac{\left(\theta_{C O}-X_{C H 4}-X_{C O 2}\right)}{\sigma} \\
& P_{H 2}=\frac{\left(\theta_{H 2}+3 \cdot X_{C H 4}-X_{C O 2}-Y_{H 2}\right)}{\sigma} \\
& \sigma=\frac{\left(1+\theta_{H 2 O}+\theta_{C O}+\theta_{C O 2}+\theta_{H 2}\right)}{P_{T}} \\
& \theta_{j}=\frac{\left(F_{j}^{o}\right)}{F_{C H 4}^{o}}
\end{aligned}
$$

where $P_{T}$ is the total pressure and $F_{j}{ }^{\circ}$ the initial flow rate of $j$ species [72]. The values of parameters of these equations in the simulated system are present in Table 2 and 3.

Table 2: Values of adsorption constants for the compounds involved in the reactions

\begin{tabular}{|l|c|c|c|c|}
\hline & $\mathrm{CH}_{4}$ & $\mathrm{H}_{2} \mathrm{O}$ & $\mathrm{CO}$ & $\mathrm{H}_{2}$ \\
\hline $\mathrm{K}(1 /$ bar $)$ & $6.65 \cdot 10^{-4}$ & $1.77 \cdot 10^{-5}$ & $8.23 \cdot 10^{-5}$ & $6.12 \cdot 10^{-9}$ \\
\hline
\end{tabular}

Table 3: Values of kinetic parameters of the involved reactions

\begin{tabular}{|l|c|c|c|}
\hline Reaction & $\begin{array}{c}\text { steam } \\
\text { reforming }\end{array}$ & $\begin{array}{c}\text { water gas } \\
\text { shift }\end{array}$ & $\begin{array}{c}\text { methanatio } \\
\mathrm{n}\end{array}$ \\
\hline $\begin{array}{l}\mathrm{k}^{\mathrm{0}} \\
\left(\mathrm{kmolbar}^{0.5} / \mathrm{kgcath}\right)\end{array}$ & $4.22 \cdot 10^{15}$ & $1.95 \cdot 10^{15}$ & $1.02 \cdot 10^{15}$ \\
\hline $\begin{array}{l}\text { Activation energy } \\
(\mathrm{J} / \mathrm{mol})\end{array}$ & 240100 & 67130 & 243900 \\
\hline
\end{tabular}

The hydrogen permeation through the palladium membrane involves with the dissociation of molecular hydrogen and the diffusion of their atoms. The flux of hydrogen depends by membrane properties and driving force (the square root of hydrogen partial pressures on both sides of the membrane) [73] (See eq. 17):

$$
J_{H 2}=\frac{Q_{p d}}{\delta} \cdot\left(P_{H 2, r}^{0.5}-P_{H 2, p}^{0.5}\right)
$$

where $\delta$ is the membrane thickness, $\mathrm{Q}_{\mathrm{pd}}$ the permeation of hydrogen, $\mathrm{PH}_{2, \mathrm{r}}$ and $\mathrm{P}_{\mathrm{H} 2, \mathrm{p}}$ the hydrogen pressure in permeate and reaction side respectively. The permeation coefficient of hydrogen is a function of the temperature according the Arrhenius equation, as below (See eq. 18):

$$
Q_{p d}=Q_{o} \cdot \exp \cdot\left(-\frac{E_{p}}{R \cdot T}\right)
$$

A differential form of hydrogen flow is expressed by the following relationship (See eq. 19):

$$
\frac{d F_{H 2, p e r m}}{d x}=J_{H 2} \cdot 2 \cdot \pi \cdot\left(r_{\circ}+\delta\right)
$$

with $r_{o}$ the inner radius and $\delta$ the thickness of the membrane. Considering the variable $\mathrm{Y}_{\mathrm{H} 2}$ as the ratio between the hydrogen flow in the permeation side and the initial flow of methane, it is possible to obtain this differential equation (see eq. 20):

$$
\frac{d Y_{H 2}}{d \varepsilon}=\frac{Q_{p d} \cdot 2 \cdot \pi \cdot\left(r_{\circ}+\delta\right) \cdot L}{\delta} \cdot 22.4 \cdot F_{C H, 4}^{\circ}
$$

where $\xi$ is the dimensionless length of the reactor, $\mathrm{F}_{\mathrm{CH} 4}^{\mathrm{O}}$ the initial flow rate of methane and $\mathrm{L}$ the length of the reactor. The mass balance for the gaseous phase is according this expression (See eq. 21):

$$
\frac{d F_{i}}{d x}=\rho \cdot \Omega \cdot \sum_{j=1}^{N_{R}=3} v_{i j} \cdot r_{j} \cdot \eta_{j}
$$

For the flow of methane and the carbon dioxide, result (See eq. 22-23):

$$
\begin{aligned}
& \frac{d F_{C H 4}}{d x}=\rho \cdot \Omega \cdot\left(r_{1} \cdot \eta_{1}+r_{3} \cdot \eta_{3}\right) \\
& \frac{d F_{C O 2}}{d x}=\rho \cdot \Omega \cdot\left(r_{2} \cdot \eta_{2}+r_{3} \cdot \eta_{3}\right)
\end{aligned}
$$

where $\Omega$ is the reactor section, $\rho$ is the catalyst density, $\eta_{1}$, $\eta_{2}, \eta_{3}$ are the effectiveness factors, $r_{1}, r_{2}, r_{3}$ are the reaction rates. The mathematical model that describes the process in a dimensional form is the following (See eq. 24-26):

$$
\begin{aligned}
& \frac{d X_{C H 4}}{d \varepsilon}=\frac{\rho \cdot \Omega \cdot L}{F_{C H, 4}^{\circ}} \cdot\left(r_{1} \cdot \eta_{1}+r_{3} \cdot \eta_{3}\right) \\
& \frac{d X_{C O 2}}{d \varepsilon}=\frac{\rho \cdot \Omega \cdot L}{F_{C H, 4}^{\circ}} \cdot\left(r_{2} \cdot \eta_{2}+r_{3} \cdot \eta_{3}\right)
\end{aligned}
$$




$$
\frac{d Y_{H 2}}{d \varepsilon}=\frac{Q_{p d} \cdot 2 \cdot \pi \cdot\left(r_{\circ}+\delta\right) \cdot L}{\delta} \cdot 22.4 \cdot F_{C H, 4}^{\circ}
$$

with $\mathrm{dx}=\mathrm{L} \cdot \mathrm{d} \varepsilon$. These equations are numerically solved through the method of Runge and Kutta using these initial conditions: $\mathrm{z}=0, \quad \mathrm{X}_{\mathrm{CH} 4}=\mathrm{X}_{\mathrm{CO} 2}=0$. Matlab software and $\mathrm{a} 4^{\text {th }}$ order algorithm are used for the numerical solution of the differential equation; the step side is equal to 0.001 . The operating conditions and reactor parameters used for modeling the integrated membrane reactor according the previous equations are shown in Table 4.

\subsection{Numaguchi Kinetic Reaction}

In the methane steam reforming process, the mainly independent reactions are the steam reforming and the shift reaction as the following (See eq. 27-28):

$$
\begin{aligned}
& \mathrm{CH}_{4}+\mathrm{H}_{2} \mathrm{O} \leftrightarrow \mathrm{CO}+3 \cdot \mathrm{H}_{2} \\
& \mathrm{CO}+\mathrm{H}_{2} \mathrm{O} \leftrightarrow \mathrm{CO}_{2}+\mathrm{H}_{2}
\end{aligned}
$$

The kinetic rate is described by the hybrid equation of Langmuir-Hinshelwood with the power law, assuming that the surface reaction is the rate-determining step (See eq. 2930). $\alpha$ and $\beta$ are the parameters for the adsorption term in the power law expression, according the Freundlich adsorption rate expression. $\mathrm{m}$ is the number of adsorption sites included in the rate.

Table 4: Operating conditions and reactor parameters

\begin{tabular}{|l|r|l|}
\hline \multicolumn{3}{|c|}{ Operating conditions and reactor parameters } \\
\hline Tubes number & 10 & \\
\hline Tube passage & 1 & \\
\hline Tube length & 900 & $\mathrm{~mm}$ \\
\hline Total length of membrane module & 748 & $\mathrm{~mm}$ \\
\hline GHSV & 384 & $\mathrm{~h}^{-1}$ \\
\hline Catalyst volume & 9.6 & $\mathrm{l}$ \\
\hline Duty of reaction & 1870 & $\mathrm{kcal} / \mathrm{h}$ \\
\hline Heat transfer coefficient, gas side & 278 & $\mathrm{kcal} / \mathrm{hm}^{2}{ }^{\circ} \mathrm{C}$ \\
\hline Heat transfer coefficient, salt side & 142 & $\mathrm{kcal} / \mathrm{hm}^{2} \mathrm{C}$ \\
\hline Overall heat transfer coefficient & 90 & $\mathrm{kcal} / \mathrm{hm}^{2}{ }^{\circ} \mathrm{C}$ \\
\hline Membrane area & 0.3 & $\mathrm{~m}^{2}$ \\
\hline Flow rate of molten salts & 800 & $\mathrm{~kg} / \mathrm{h}$ \\
\hline
\end{tabular}

$$
\begin{aligned}
& r_{r f} \\
& =k_{R}{ }^{o} \cdot \exp \left(-\frac{E_{p}}{R \cdot T}\right) \\
& \cdot \frac{k_{r} \cdot\left(P_{C H 4} \cdot P_{H 2 O}-P_{C O} \cdot \frac{P_{H 2}^{3}}{k_{P}}\right)}{\left(P_{C H 4}^{\alpha_{R}} \cdot P_{H 2 O}^{\beta_{R}}\right) \cdot\left(1+\sum_{k=1}^{k} K_{k} \cdot P_{k}\right)^{m}} \\
& k_{r}=k_{R}{ }^{o} \cdot \exp \left(-\frac{E_{p}}{R \cdot T}\right)
\end{aligned}
$$

In methane steam reforming, the adsorption equilibrium constant for steam is larger respect to other components. For this reason, the rates of the reactions according the Numaguchi kinetic are obtained [72] (See eq. 31-32):

$$
\begin{aligned}
r_{r f}=k_{R}{ }^{o} \cdot \exp \left(-\frac{E_{R}}{R \cdot T}\right) \cdot \frac{\left(P_{C H 4}-P_{C H 4(e q)}\right)}{\left(P_{C H 4}^{\alpha_{R}} \cdot P_{H 2 O}^{\delta_{R}}\right)} \\
r_{s f}=k_{S}^{o} \cdot \exp \left(-\frac{E_{S}}{R \cdot T}\right) \\
\cdot \frac{\left(P_{C O}-P_{C O(e q)}\right)}{\left(P_{C H 4}^{\alpha_{S}} \cdot P_{H 2 O}^{\delta_{S}}\right)}
\end{aligned}
$$

where $r_{r f}$ is for the steam reforming reaction, $r_{s f}$ is for the shift reaction, $\mathrm{P}_{\mathrm{CH} 4(\mathrm{eq})}$ and $\mathrm{P}_{\mathrm{CO}(\mathrm{eq})}$ are the pressures at equilibrium conditions and $\mathrm{R}$ the constant of universal gas. Table 5 shows the values of parameters for the reactions according the Numaguchi kinetic [72]:

Table 5: Values of parameters for Numaguchi kinetic

\begin{tabular}{|c|r|l|}
\hline \multicolumn{3}{|c|}{ Fitted parameters } \\
\hline $\mathrm{k}_{\mathrm{R}}^{\mathrm{o}}$ & $92 \cdot 10^{8}$ & \\
\hline $\mathrm{E}_{\mathrm{R}}$ & 106.87 & $\mathrm{~kJ} / \mathrm{mol}$ \\
\hline$\alpha_{\mathrm{R}}$ & 0 & \\
\hline$\delta_{\mathrm{R}}$ & 0.596 & \\
\hline $\mathrm{k}_{\mathrm{S}}^{\mathrm{o}}$ & $8.688 \cdot 10^{5}$ & \\
\hline $\mathrm{E}_{\mathrm{s}}$ & 54.531 & $\mathrm{~kJ} / \mathrm{mol}$ \\
\hline$\alpha_{\mathrm{S}}$ & 0 & \\
\hline$\delta_{\mathrm{S}}$ & 0 & \\
\hline
\end{tabular}

\subsection{Experimental Analysis of Pressure Drops inside \\ the Foams}

Ceramic or metallic foams with open structures are important for industrial application, in recent years. Infect, they have high specific surface area, high porosity, low density, favorable mechanical, thermal and corrosion resistance. For these reasons, they can be used as support in the reaction catalyst [70]. It is necessary to increase the knowledge of their hydrodynamic properties: studies are about the relation of foam structural parameters to pressure drops. A review of pressure drops correlations in foams is provided by Edouard et al. [74] and are based on the DarcyForchheimer equation (See eq. 33):

$$
\frac{\Delta P}{\Delta L}=\frac{\mu}{K} \cdot \mathrm{u}+\rho \cdot C \cdot u^{2}
$$

where $\Delta L$ is the thickness (or length) of the porous media, $\Delta p$ is the pressure drop, $u$ is the flow velocity, $\rho$ is the medium density, $\mu$ is the medium viscosity, $K$ is the permeability and $C$ is the drag force coefficient of the porous media. The term $\rho C V^{2}$ considers the inertia effects. For creeping flow in porous media, the Darcy's law is obtained. The key geometrical parameters of the foam are its porosity $(\varepsilon)$ which is the ratio of the void $\operatorname{space}\left(\mathrm{V}_{\text {void }}\right)$ to total volume, 
$\left(\mathrm{V}_{\text {total }}\right)$ occupied by the foam, the foam strut diameter $\left(\mathrm{d}_{\text {strut }}\right)$, the mean pore diameter $\left(d_{p}\right)$, the pore per linear inch number(ppi) and specific surface area as a ratio of the surface in contact with the flow $(S)$ to the whole volume occupied by the foam. These parameters are correlated between them.

For the measures of pressure drops a sample is used: $\mathrm{SSiC}$ foams coated with $\mathrm{Ni}(10) / \mathrm{CeLaZr}$ catalyst as reported in Fig. 2.

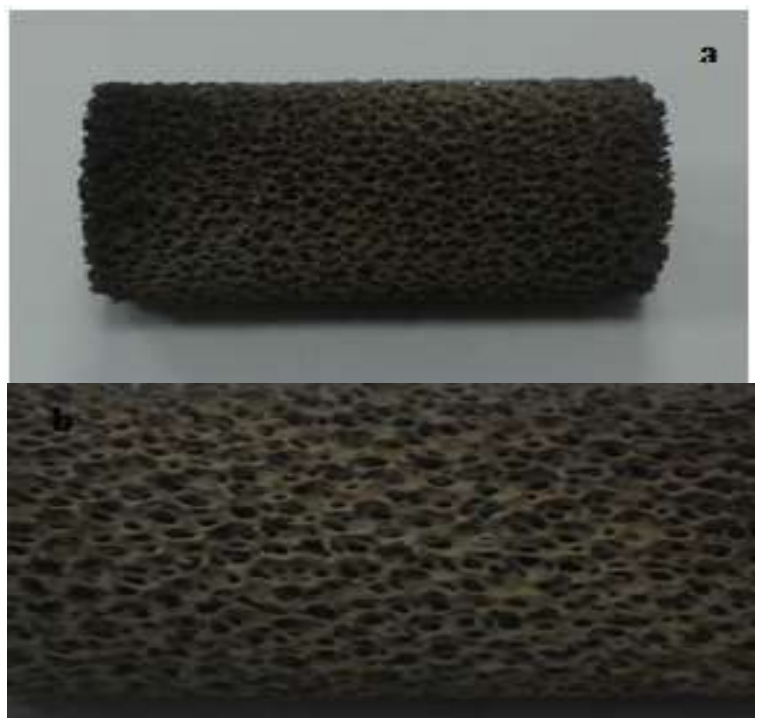

Fig-2 a) Images of SSiCfoams coated with $\mathrm{Ni}(10) / \mathrm{CeLaZr}$ catalyst; b)Stereomicroscopic images of SSiCfoams coated with $\mathrm{Ni}(10) / \mathrm{CeLaZr}$ catalyst

Table 6 reports the characteristics of the catalyst sample.

Table 6: Characteristics of SSiC foams coated with $\mathrm{Ni}(10) / \mathrm{CeLaZr}$ catalyst

\begin{tabular}{|c|c|c|c|c|c|}
\hline \multicolumn{4}{|c|}{ SSiC-foam } & \multicolumn{2}{c|}{ Ni(10)/CeZrLa } \\
\hline $\begin{array}{c}\mathbf{M} \\
(\mathbf{g})\end{array}$ & $\begin{array}{c}\mathbf{d}_{\mathbf{f}} \\
(\mathbf{m m})\end{array}$ & $\begin{array}{c}\mathbf{H}_{\mathbf{f}} \\
(\mathbf{m m})\end{array}$ & $\begin{array}{c}\mathbf{\varepsilon} \\
(\boldsymbol{\%})\end{array}$ & $\begin{array}{c}\mathbf{M} \\
(\mathbf{g})\end{array}$ & $\begin{array}{c}\text { loading } \\
(\mathbf{g} / \mathbf{l})\end{array}$ \\
\hline 1.62 & 14 & 21.2 & 84.24 & 0.9 & 275.78 \\
\hline
\end{tabular}

The parameters of the catalyst as permeability and drag coefficient are evaluated from the experimental measures of pressure drops and the fitting of the obtained data. These parameters are present in Darcy-Forchheimerrelation, so the pressure drops of ceramic foam are characterized.

To evaluate these parameters, an experimental test is realized: compressed air is sent within the sample, as Fig. 3 shows and the flow rate is measured by the position of rotameters, as shown in Fig. 4 a. A system of solenoid valves regulars the flow rate of compressed air. A digital manometer and a differential pressure gauge measure the pressure drops inside the foams, as shown in Fig. b.

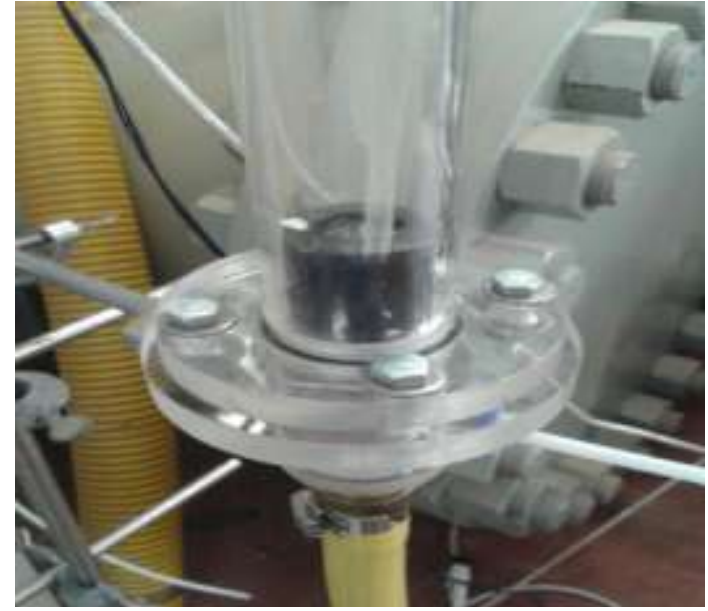

Fig-3. Sample of catalyst inside the tube where compressed air is sent from the bottom during the experimental tests
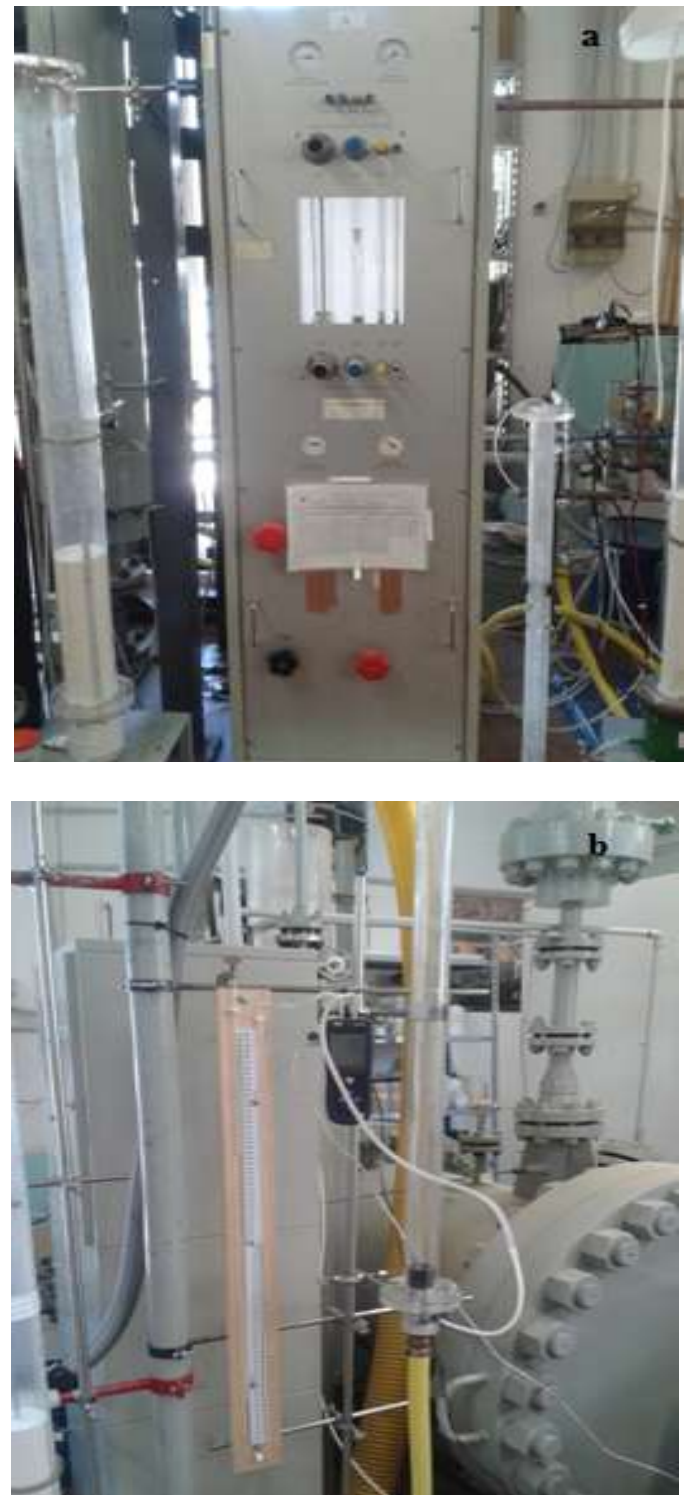

Fig-4. Experimental apparatus used to measure the pressure drops inside the catalyst sample (fig. 4a shows the rotameters used to measure the flow rate of compressed air, fig. $4 \mathrm{~b}$ shows the digital and differential manometer used to measure the pressure drops) 
An isotropy test is used to ensure the property of the catalyst: the position of sample is inverted and compressed air is sent again, while the digital and differential manometer measure the pressure drops inside the catalyst.

\section{RESULTS AND DISCUSSIONS}

\subsection{Modeling of the Integrated Membrane Reactor}

\section{Using the XU and Froment Kinetic Reaction}

The equations system to model the integrated membrane reactor is solved using the $\mathrm{Xu}$ and Froment kinetic reaction and the trend of methane and carbon dioxide conversion as a function of temperature and pressure is obtained, as shown in the following figures. For the trend of methane and carbon dioxide conversion, reported in Fig. 5 and 6 respectively, the results are comparable with the studies of Shu et al. [75] and Lin et al. [76].

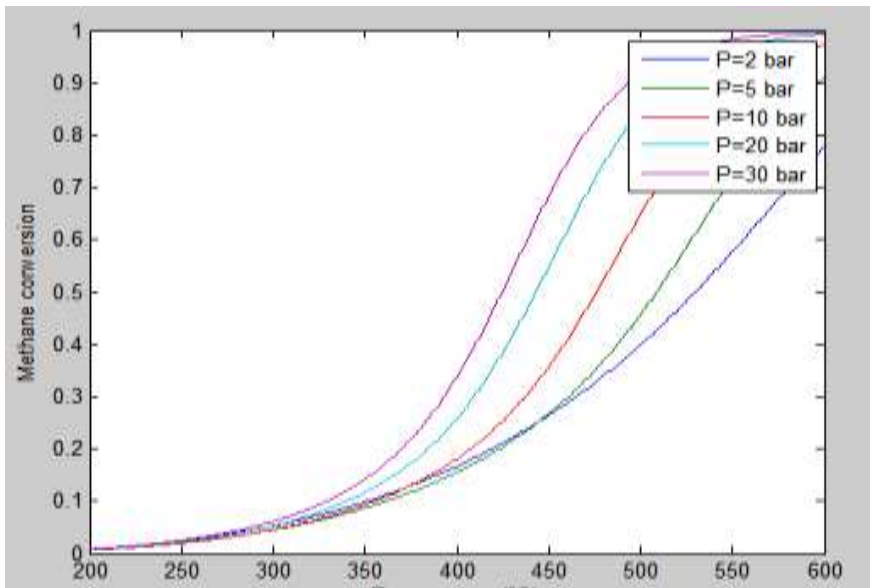

Fig-5. Performance of methane conversion as a function of temperature and pressure inside the integrated membrane reactor according to the $\mathrm{Xu}$ and Froment kinetic

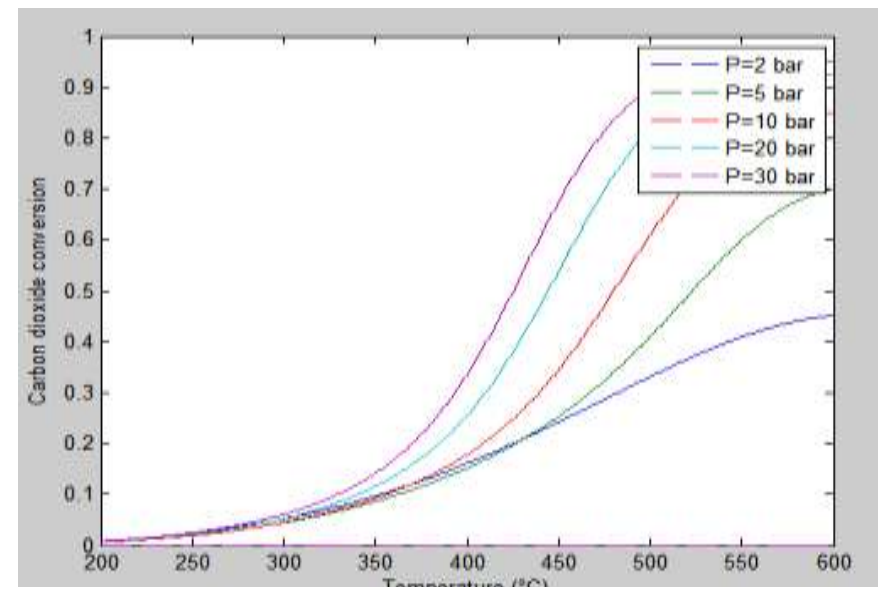

Fig-6. Performance of carbon dioxide conversion as a function of temperature and pressure inside the integrated membrane reactor according to the $\mathrm{Xu}$ and Froment kinetic

For the integrated membrane reactor temperature and pressure have a positive effect on methane and carbon dioxide conversion: the chemical equilibrium is shift to the products, resulting in higher conversion.
As the temperature increases, the hydrogen permeation rate through the membrane and the reaction rate increase producing a higher methane conversion. Equally, higher pressures and therefore higher partial pressure inside the reaction increases the driving force of hydrogen, resulting in a higher conversion of methane. Infect, the fluid temperature increases when the pressure increases. Conversions next to unit are obtained for values of pressure next to 30 bar and temperatures greater than $500{ }^{\circ} \mathrm{C}$. Temperature and pressure have an important role in the reaction kinetic, being the reaction endothermic. A similar consideration can be drawn for the hydrogen production, shown in Fig. 7. Higher pressures contribute to the transfer of hydrogen from the reaction zone to permeation zone; an ideal value of 4 is asymptotically reached with a pressure of 30 bar [77]. The positive effect of the pressure is less significant for values of pressures that are higher than 5 bar. The yields of hydrogen are proportional to methane conversion.

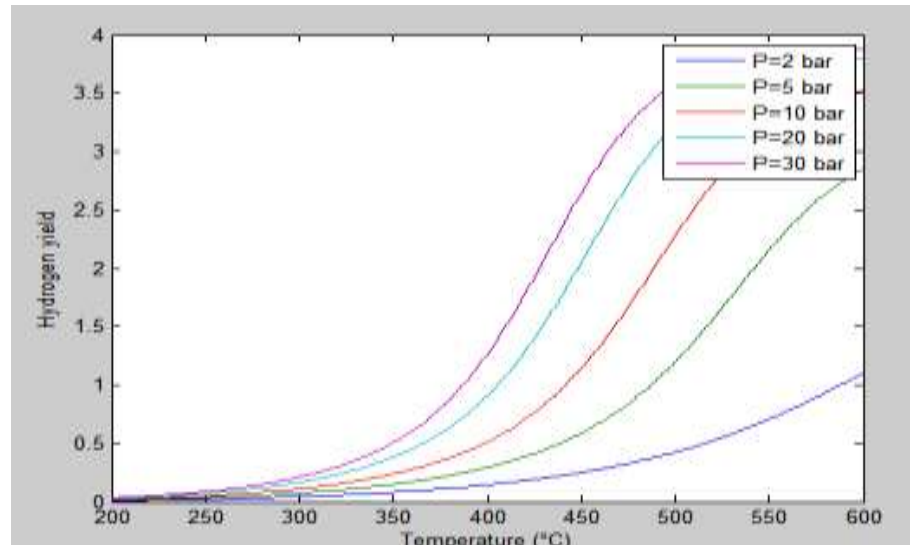

Fig-7. Performance of hydrogen yield as a function of temperature and pressure inside the integrated membrane reactor according to the $\mathrm{Xu}$ and Froment kinetic

Fig. 8 shows the methane conversion as function of pressure and dimensionless length of the reactor. It is evident that the kinetic reaction is very fast: the conversion is unitary in all length of the reactor. Then, using data related to the existing integrated membrane reactor, it is evident that the $\mathrm{Xu}$ and Froment kinetic used in literature is not suitable for the description of this process.

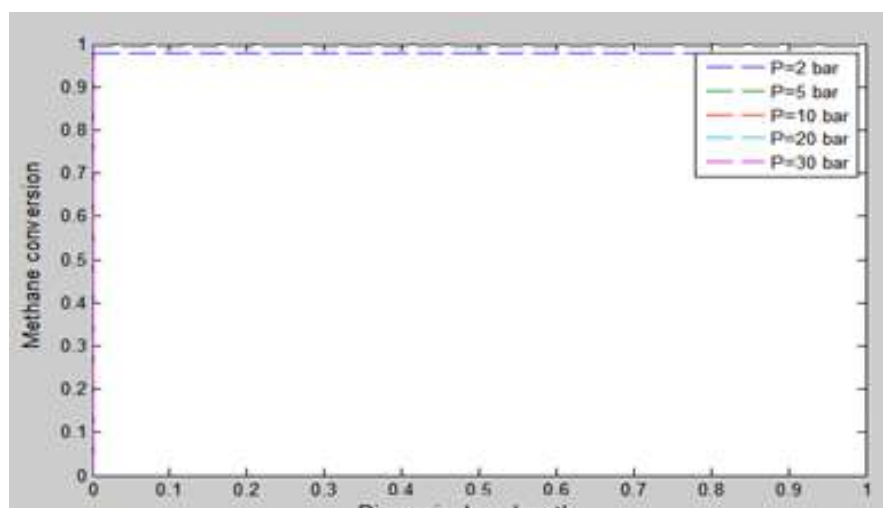

Fig-8. Performance of methane conversion as a function of dimensionless length of the reactor and pressure inside the integrated membrane reactor according to the $\mathrm{Xu}$ and Froment kinetic 
Fig. 9 shows the methane conversion as a function of pressure and temperature. An optimal value of methane conversion can be obtained with pressure and temperature equal to 30 bar and $500{ }^{\circ} \mathrm{C}$ respectively.

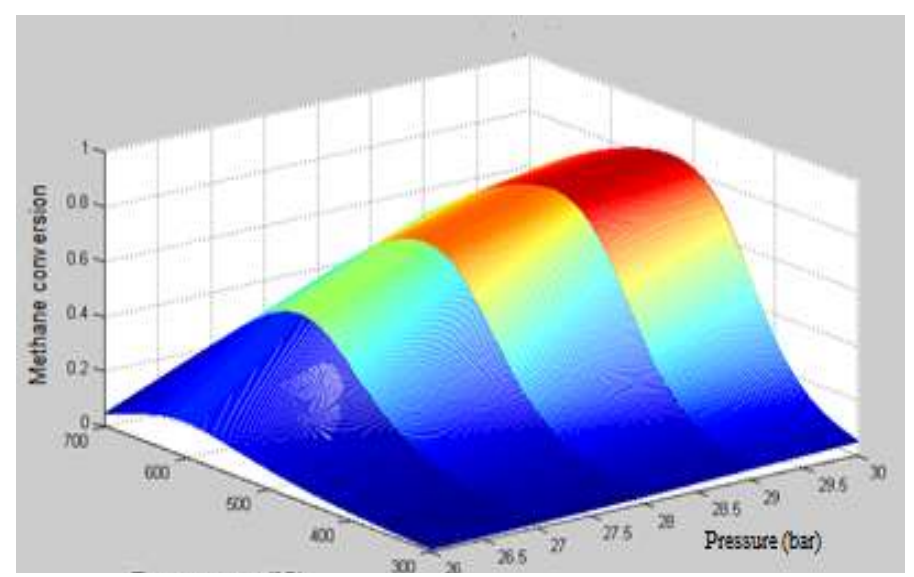

Fig-9. Performance of methane conversion as a function of temperature and pressure inside the integrated membrane reactor in 3D plot according to the $\mathrm{Xu}$ and Froment kinetic

A comparison with a corresponding packed reactor can be made by evaluating delta parameter, which represents the efficiencies difference of the two types of reactors. As shown in Fig. 10, high values of delta should indicate where the membrane reactor is more efficient respect to a packed reactor: with high pressures and medium temperatures the integrated membrane reactor is advantageous respect to a packed one.

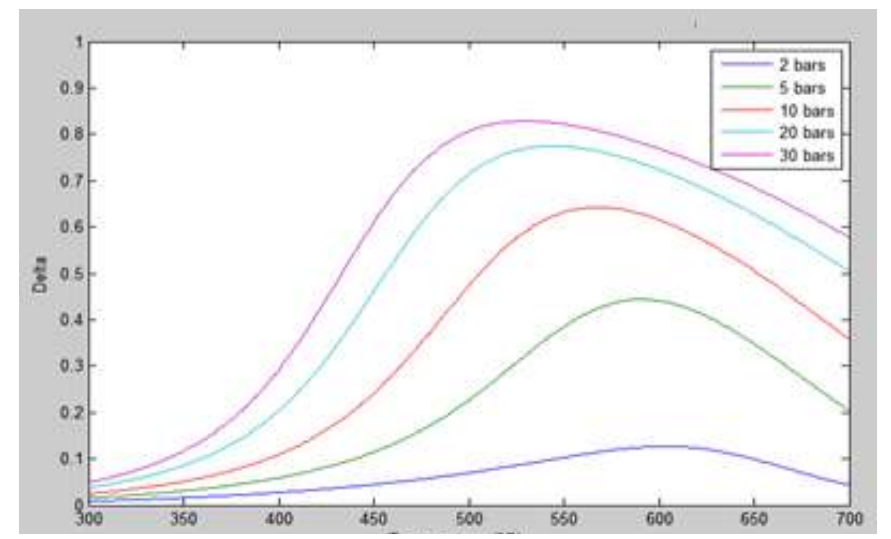

Fig-10. Performance of delta function as a function of temperature and pressure of the reactor

\subsection{Modeling of the Integrated Membrane Reactor}

\section{Using the Numaguchi Kinetic Reaction}

Fig. 11 and 12 show the results obtained by modeling the system with theNumaguchi kinetic. In Fig. 11 the methane conversion increases with the increase of pressure and temperature, for the same reasons analyzed first. Analog consideration can be treated for carbon dioxide conversion as Fig. 12 shows.

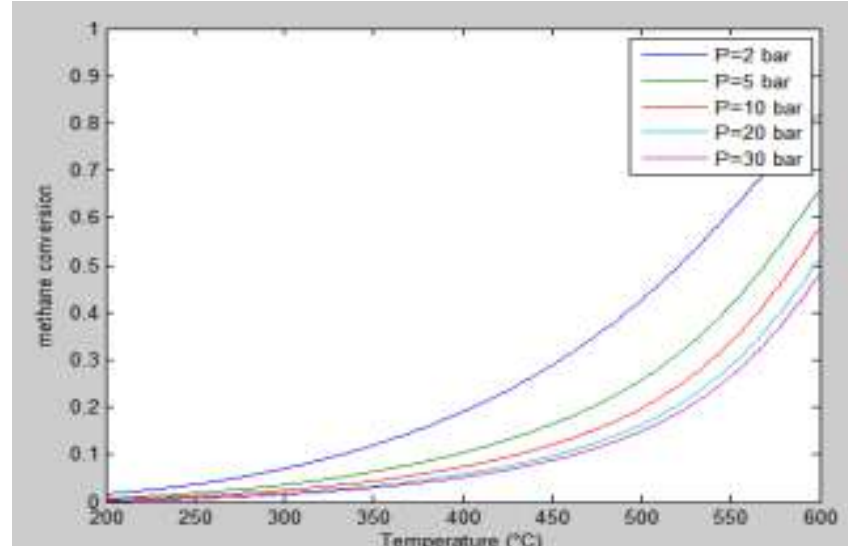

Fig-11. Performance of methane conversion as a function of temperature and pressure inside the integrated membrane reactor according to the Numaguchi kinetic

Temperature and pressure have a positive effect on hydrogen production as shown in Fig. 13. Fig. 14 shows the methane conversion as a function of pressure and dimensionless of the reactor: the used kinetic is suitable to describe the process. The pressure has a positive effect on dimensionless length and the trend is similar to works of Kyriakides et al. [77], Patrascu and Sheintuch [44] and Castillo et al. [78]. High value of methane conversion can be obtained with high pressure.

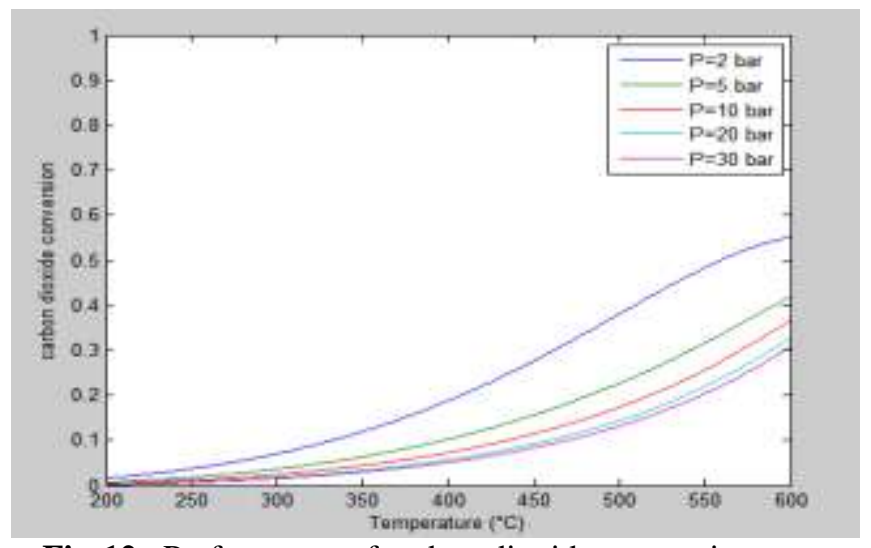

Fig-12. Performance of carbon dioxide conversion as a function of temperature and pressure inside the integrated membrane reactor according to the Numaguchi kinetic

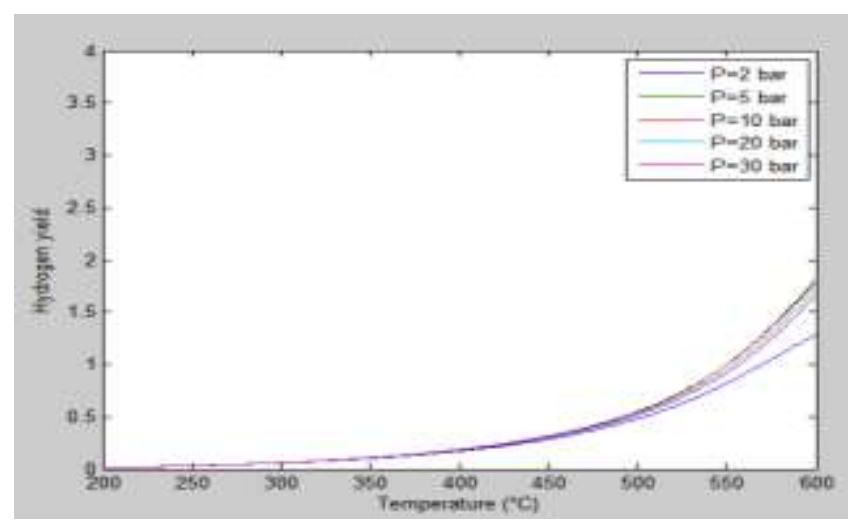

Fig-13. Performance of hydrogen yield as a function of temperature and pressure inside the integrated membrane reactor according to the Numaguchi kinetic. 


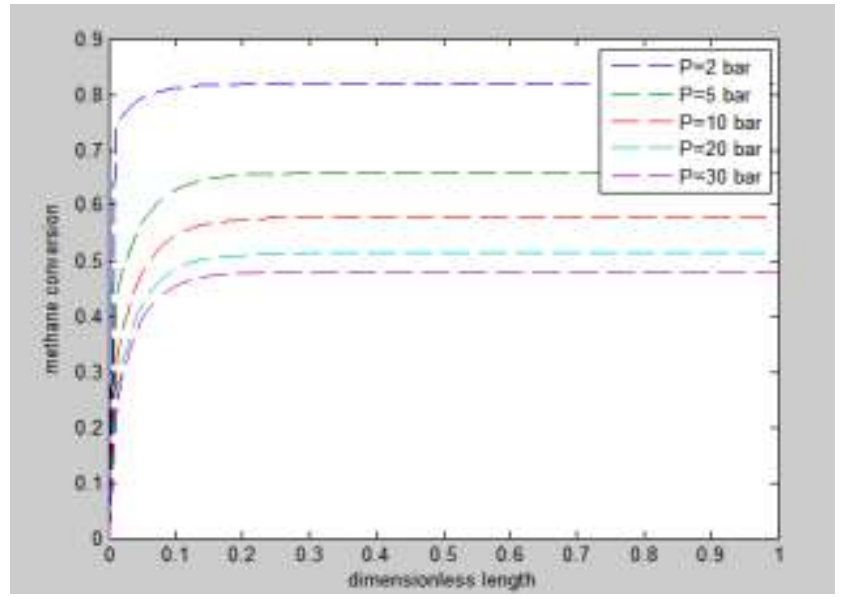

Fig-14. Performance of methane conversion as a function of dimensionless reactor length and pressure inside the integrated membrane reactoraccording to the Numaguchi kinetic

\subsection{Experimental Analysis of Pressure Drops Inside}

\section{The Foams}

Pressure drops through foams depend on foam microstructure and fluid velocity. A correct estimations of pressure drops inside the foams can be used to do some previsions during the operation of the process. To this purpose, parameters as permeability $(\mathrm{K})$ and drag coefficient (C) are important and should be defined properly. These parameters are estimated by the fitting of experimental data, according the model of Hazen-Dupuit-Darcy or called as Forchheimer-extended Darcy equation [79]. The pressure drops per unit of length as function of fluid velocity used in experimental tests (compressed air)are provided according the Hazen-Dupuit-Darcy equation (See eq. 34):

$$
y=34.55 \cdot u^{2}+2.27 \cdot u
$$

where $y$ is the pressure drop per unit of length of catalyst and $\mathrm{u}$ the fluid velocity, calculated dividing the volumetric flow rate by the cross-sectional area. The pressure drops across the foam are a quadratic function of the flow velocity. The length of catalyst used in the experimental tests is equal to $5 \mathrm{~cm}$ while the section equal to $0.00203 \mathrm{~m}^{2}$. Fig. 15 shows the trend of pressure drops as a function of fluid velocity: the experimental results are in good agreement with the model with $\mathrm{R}^{2}>98 \%$. Also, the trend is according to previous studies of Bhattacharya et al. [80] and Boomsma and Poulikakos [81]: the pressure drops increase with the increasing of velocity according a quadratic equation. Results suggest that the pressure drops of foams are much lower compared to a packed bed of spheres and short contact times are present. Richardson et al. [82] find that the pressure drops through foams are about ten times lower respect to a spherical particles fixed bed.

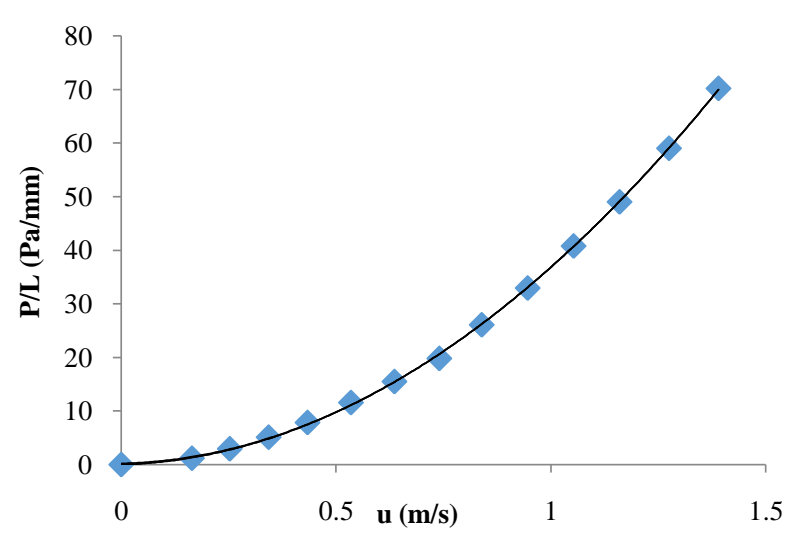

Fig-15. Performance of pressure drops per unit of length of catalyst as a function of fluid velocity used in the experimental tests

The value of permeability $\mathrm{K}$ and drag coefficient $\mathrm{C}$ of ceramic foam obtained from the regressions of experimental data are equal to $4.89 \cdot 10^{-7} \mathrm{~m}^{2}$ and $1.81 \mathrm{~s}^{2} / \mathrm{m}$ respectively. The value of $K$ and $C$ are calculated as $K=\mu / \alpha$ and $C=\beta / \rho$, where dynamic viscosity $(\mu)$ and density of compressed air ( $\rho)$ are taken as $0.000017 \mathrm{~kg} / \mathrm{ms}$ and $1.225 \mathrm{~kg} / \mathrm{m}^{3}$, respectively. $\mathrm{K}$ and $\mathrm{C}$ values are related to the pore diameters of the foams: in general, the pore diameter has a positive effect on $\mathrm{K}$ parameter and negative effect on $\mathrm{C}$ parameter. [83]. Several works show the relation between porosity and permeability: the permeability increases with the increasing of porosity [80, 81]. The concentrated pressure drops produced during the experimental tests are neglected, because are insignificant (between 0 and 0.06 $\mathrm{mmH}_{2} \mathrm{O} / \mathrm{mm}$, as obtained by experimentation). The drag force $\mathrm{C}$ allows to have an accurate estimation of the pressure drops and depends on porosity [83]. Diedericks and Du Plessis [85] show that coefficient $C$ is significant with higher flow velocity. Permeability of the metal foam is more accurate if determined experimentally and it is difficult to model due to the complex structure of these materials. Several researchers correlate the permeability with structural parameters of metal foam [81]. Antohe et al. [86] show that $\mathrm{K}$ and $\mathrm{C}$ are related to fluid velocity.

From isotropy test it is possible to notice that the catalyst does not respect this property because the equation for pressure drops is not equal to that found previously (See eq. $35)$.

$$
y=35.66 \cdot u^{2}+8.56 \cdot u
$$

where $\mathrm{y}$ is the pressure drop per unit of length of catalyst and $u$ the fluid velocity. Fig. 16 shows the trend of pressure drops as a function of fluid velocity. In this case, the value of $\mathrm{K}$ and $\mathrm{C}$ coefficients are respectively equal to $4.76 \cdot 10^{-7}$ $\mathrm{m}^{2}$ and $6.84 \mathrm{~s}^{2} / \mathrm{m}$. 


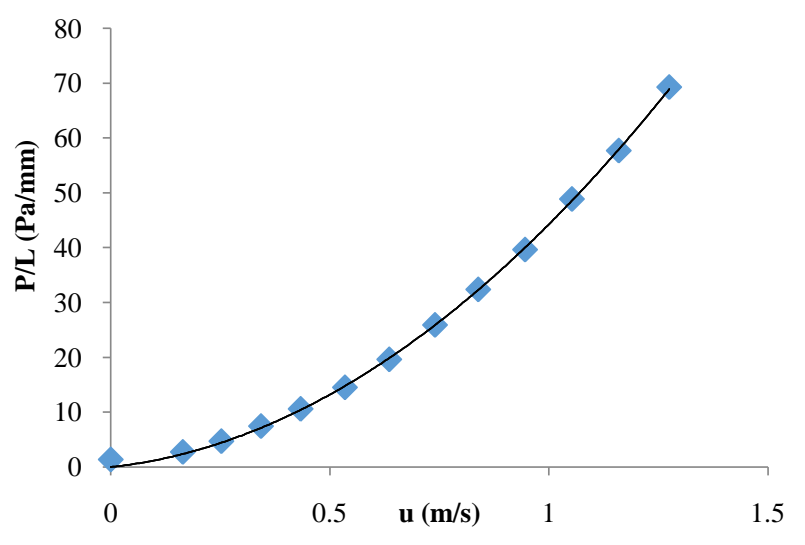

Fig-16. Performance of pressure drops per unit of length of catalyst as a function of fluid velocity used in the experimental isotropy tests

\section{CONCLUSION}

Pure hydrogen production is of great interest, because hydrogen is an energy green carrier and methane steam reforming is commonly used for its production. Integrated membrane reactors enable a pure hydrogen stream and allows that the reaction take places at significantly lower temperatures than conventional reactors. Infect, membrane reactors can do the reaction and separation simultaneously in order to produce hydrogen.

In this research methane steam reforming in an integrated membrane reactor is studied experimentally and from a modeling point of view. Catalyst supported on ceramic foam ( $\mathrm{SSiC}$ foams coated with $\mathrm{Ni}(10) / \mathrm{CeLaZr}$ ) is used to ensure an uniform temperature distribution. It is a first integrated membrane reactor at pilot plant in Europe.

Results suggest that the $\mathrm{Xu}$ and Froment kinetic, commonly used in the literature, is not suitable to describe the system, being very fast. Acceptable results are obtained using the Numaguchi kinetic. So a new kinetic is used to describe a methane steam reforming reaction inside the integrated membrane reactor.

An analysis to study the effect of pressure and temperature is carried out: these parameters have a positive effect on methane and carbon dioxide conversion and hydrogen yield.

The developed model can form the basis for an optimal design and process control studies of reactor system aiming at high methane conversion, high hydrogen recovery yield and a suitable energy management procedure, while ensuring safe operating conditions. Several experimental tests are carried out to measure the pressure drops inside the catalyst sample according the Hazen-Dupuit-Darcy equation; from regression of experimental data, drag coefficient and permeability are obtained. The isotropic test of this kind of foam is not satisfied.

\section{ACKNOWLEDGEMENT}

The author of the study would like to thank the European Commission for funding this work.

\section{REFERENCES}

[1]. Y.W. Ohmori, S. Kataoka, T. Yamamoto, A. Endo, M. Nakaiwa, et al. A comparative simulation study of methane steam reforming in a porous ceramic membrane reactor using nitrogen and steam as sweep gases. International Journal of Hydrogen Energy. 33 (2008) 685-92.

[2]. D. Dasa, T.N. Veziroglu, Advances in biological hydrogen production processes. Int. J. Hydrogen Eng. 33 (2008) 6046-57.

[3]. M.P. Gimeno, Z.T.Wub, J. Solerc, J. Herguidoa, K. Lib, M. Menéndez, Combination of a Two-Zone Fluidized Bed Reactor with a Pd hollow fiber membrane for catalytic alkane dehydrogenation. Chemical Engineering Journal. 155 (2009) 298-303.

[4]. A. Brunetti, A. Caravella, G. Barbieri, E. Drioli, Simulation study of water gas shift reaction in a membrane reactor. J. Membr. Sci. 306 (1-2) (2007) 329-340.

[5]. M. Sjardin, K.J. Damen, A.P.C. Faaij, Techno-economic prospects of small-scale membrane reactors in a future hydrogen-fuelled transportation sector. Energy 31 (2006) 2523-2555.

[6]. L. Capobiancoa, Z. Del Pretea, P. Schiavettia, V. Violante, Theoretical analysis of a pure hydrogen production separation plant for fuel cells dynamical applications. International Journal of Hydrogen Energy. 31 (2006) 1079 - 1090.

[7]. J. Tong, Y. Matsumura, Pure hydrogen production by methane steam reforming with hydrogen-permeable membrane reactor. Catalysis Today. 111 (2006) 147-152.

[8]. M. Saric, Y.C. van Delft, R.Sumbharaju, D.F. Meyer, Arend de Groot, Steam reforming of methane in a benchscale membrane reactor at realistic working conditions. Catalysis Today. 193 (2012) 74-80.

[9]. Y. Bi, H. Xu, W.Li, A. Goldbach, Water-gas shift reaction in a $\mathrm{Pd}$ membrane reactor over $\mathrm{Pt} / \mathrm{Ce} 0.6 \mathrm{Zr} 0.4 \mathrm{O} 2$ catalyst. International journal of hydrogen energy. 34 (2009) 2965-2971.

[10]. L.C. Silva, V.V. Murata, C.E. Hori, A.J. Assis, Optimization of a Membrane Reactor for Hydrogen Production Through Methane Steam Reforming Using Experimental Design Techniques and NPSOL, EngOpt 2008 - International Conference on Engineering Optimization, Rio de Janeiro, Brazil, 01-05 June 2008.

[11]. H.W. Deckeman, J.W. Fulton, J.M. Grenda, F. Hershkowitz, Electric power generation with heat exchanged membrane reactor. CA2414657 (C)-2011-0524.

[12]. W. Sufang, W. Cheng, W. Xieqing, Decarburization and dehydrogenation double-intensification methane and steam reforming hydrogen production method and device, CN102674247 (A)-2012-09-19.

[13]. Y. Mei, L. Shulian, J. Fengjun, C. Guangwen, Method for producing hydrogen by reforming methanol steam. CN102145876 (A) - 2011-08-10 
[14]. B. Morico, A.Salladini, G. Iaquaniello, Method and system for the production of the hydrogen, WO 2013137720 A1, 19-09-2013

[15]. Y. Chen, Y. Wang, H. Xu, G. Xiong, Hydrogen production capacity of membrane reformer for methane steam reforming near practical working conditions. J.Membr. Sci. 322 (2008) 453-459.

[16]. B. Dittmar, A. Behrens, N. Schödel, M. Rüttinger, T. Franco, G. Straczewski, R.Dittmeyer, Methane steam reforming operation and thermal stability of newporous metal supported tubular palladium composite membranes, Int. J.Hydrogen Energy. 38 (2013) 8759-8771.

[17]. J. Xuan, M.K.H. Leung, D.Y.C. Leung, M. Ni, integrating chemical kinetics with CFD modeling for autothermal reforming of biogas. International Journal of Hydrogen Energy. 34 (2009) 9076-86.

[18]. M. De Falco, G. Iaquaniello, A. Salladini, Experimental tests on steam reforming of natural gas in a reformer and membrane modules, (RMM) plant. Journal of Membrane Science. 368 (1-2) (2011a) 264-274.

[19]. F. Borgognoni, S. Tosti, M. Vadrucci, A. Santucci, Pure hydrogen production in a $\mathrm{Pd}-\mathrm{Ag}$ multi-membranes module by methane steam reforming.Int. J. Hydrogen Energy. 36 (2011) 7550-7558.

[20]. M. De Falco, D. Barba, S. Cosenza, G. Iaquaniello, L. Marrelli, Reformer and membrane modules plant powered by a nuclear reactor or by a solar heated molten salts: Assessment of the design variables and production cost evaluation. International Journal of Hydrogen Energy. 33 (20) (2008) 5326-5334.

[21]. D.S.A. Simakov and M. Sheintuch, Experimental optimization of an autonomous scaled-down methane membrane reformer for hydrogen generation. Industrial and Engineering Chemistry Research. 49 (3) (2010) 1123-1129. [22]. R.Y. Chein, Y.C. Chen, Y. Sheng Lin, J.N. Chung, Experimental study on the hydrogen production of integrated methanol-steam reforming reactors for PEM fuel cells. International Journal of Thermal Sciences. 50 (2011) 1253-1262.

[23]. W. Yu, T. Ohmoria, S. Kataokaa, T. Yamamotoa, A. Endoa, M. Nakaiwaa, N. Itoh, A comparative simulation study of methane steam reforming in a porous ceramic membrane reactor using nitrogen and steam as sweep gases. International Journal of hydrogen energy. 33 (2008) 685692.

[24]. D. Mendes, S. Sa, S. Tosti, J.M. Sousa, L.M. Madeira, A. Mendes, Experimental and modeling studies on the lowtemperature water-gas shift reaction in a dense $\mathrm{Pd}-\mathrm{Ag}$ packed-bed membrane reactor. Chem. Eng. Sci. 66 (2011) 2356-67.

[25]. A.S. Augustine, Y.H. Ma, N.K. Kazantzis, High pressure palladium membrane reactor for the high temperature water-gas shift reaction. International Journal of Hydrogen Energy. 36 (2011) 5350-60.

[26]. R. Sanz, J.A. Calles, D. Alique, L. Furones, S. Ordonez, P. Marın, et al. Preparation, testing and modelling of a hydrogen selective $\mathrm{Pd} / \mathrm{YSZ} / \mathrm{SS}$ composite membrane. International Journal of Hydrogen Energy. 36 (2011) 1578393.
[27]. S. Hao, D.S. Sholl, Computational prediction of durable amorphous metal membranes for $\mathrm{H}_{2}$ purification. J. Membr. Sci. 381 (1-2) (2011) 192-196.

[28]. E. Ozdogan, J. Wilcox, Investigation of $\mathrm{H}_{2}$ and $\mathrm{H}_{2} \mathrm{~S}$ adsorption on niobium-and copper-doped palladium surfaces. J. Phys. Chem. B 114 (40) (2010) 12851-12858.

[29]. C.G. Sonwane, J. Wilcox, Y.H. Ma, Solubility of hydrogen in $\mathrm{Pd} / \mathrm{Ag}$ and $\mathrm{Pd} / \mathrm{Au}$ binary alloys using density functional theory. J. Phys. Chem. B. 110 (48) (2006) 2454924558.

[30]. S. Tosti, L. Bettinali, S. Castelli, F. Sarto, S. Scaglione, V. Violante, Sputtered, electroless, and rolledpalladiumceramicmembranes. J Membr Sci. 196 (2002) 241-9.

[31]. J.T. Richardson, M. Garrait, J.K. Hung, Carbon dioxide reforming with $\mathrm{Rh}$ and $\mathrm{Pt}-\mathrm{Re}$ catalysts dispersed on ceramic foam supports. Applied Catalysis A: General. 225 (2003) 69-82.

[32]. N. Gokon, Y. Osawa, D. Nakazawa, T. Kodama, Kinetics of $\mathrm{CO}_{2}$ reforming of methane by catalytically activatedmetallic foam absorber for solar receiver-reactors. International Journal of Hydrogen Energy. 34 (2009) 17871800.

[33]. L. Giani, C. Cristiani, G. Groppi, E. Tronconi, Washcoating method for $\mathrm{Pd} / \gamma-\mathrm{Al}_{2} \mathrm{O}_{3}$ deposition on metallic foams, Applied Catalysis B: Environmental. 62 (2006) 121131.

[34]. K. Sutthiumporn, T. Maneerung, Y. Kathiraser, S. Kawi, $\mathrm{CO}_{2}$ dry-reforming of methane over $\mathrm{La} 0.8 \mathrm{Sr} 0.2 \mathrm{Ni0} .8 \mathrm{M} 0.2 \mathrm{O}_{3}$ perovskite $(\mathrm{M}=\mathrm{Bi}, \mathrm{Co}, \mathrm{Cr}, \mathrm{Cu}$, $\mathrm{Fe}$ ): roles of lattice oxygen on $\mathrm{C}-\mathrm{H}$ activation and carbon suppression. International Journal of Hydrogen Energy. 37 (2012) 11195-11207.

[35]. A. Iulianelli et al., $\mathrm{H}_{2}$ production by low pressure methane steam reforming in a $\mathrm{Pd}-\mathrm{Ag}$ membrane reactor over a Ni-based catalyst: experimental and modeling. Int. J. Hydrogen Energy. 35 (20) (2010) 11514-11524.

[36]. H.F. Chang et al., Auto-thermal reforming of methane for producing highpurity hydrogen in a $\mathrm{Pd} / \mathrm{Ag}$ membrane reactor, Int. J. Hydrogen Energy. 35 (23) (2010) 1298612992.

[37]. C.Y. Zhao, Review on thermal transport in high porosity cellular metal foams with open cells. International Journal of Heat and Mass Transfer. 55 (2012) 3618-3632.

[38]. P.J. Tan, S.R. Reid, J.J. Harrigan, Z. Zou, S. Li, Dynamic compressive strength properties of aluminum foams, Part I - experimental data and observations. Journal of the Mechanics and Physics of Solids. 53 (2005) 2174 2205.

[39]. S. Lim and J. Bae, Auto-thermal reforming over a Pt/Gddoped ceria catalyst: Heat and mass transport limitations in the steam reforming section. Int. J. Hydrogen Energy. 35 (2010) 6717-6725.

[40]. W. Lu, C.Y. Zhao. Thermal analysis on metal-foam filled heat exchangers. Part I: Metal-foam filled pipes, Int. J. Heat Mass Transfer. 49 (2006) 2751-2761.

[41]. N. Gokon, Y. Yamawaki, D. Nakazawa,T.Kodama, $\mathrm{Ni} / \mathrm{MgO}-\mathrm{Al}_{2} \mathrm{O}_{3}$ and $\mathrm{Ni}-\mathrm{Mg}-\mathrm{O}$ catalyzedSiC foam absorbersfor high temperature solar reforming of methane. Int.J.Hydrogen Energy. 35 (2010) 7441-7453.

[42]. H. Liu, S. Li, S. Zhang, J. Wang, G. Zhou, L. Chen, X. Wang, Catalytic performance of novel $\mathrm{Ni}$ catalysts 
supported onSiC monolithic foam in carbon dioxide reformingof methane to synthesis gas. Catal. Commun 9 (2008) 51-54.

[43]. J. Qi, Y. Sunb, Z. Xiec, M. Collins, H. Dua, T. Xiong, Development of $\mathrm{Cu}$ foam-based $\mathrm{Ni}$ catalyst for solar thermal reforming of methane with carbon dioxide. Journal of Energy Chemistry. 24 (2015) 786-793.

[44]. M. Patrascu, M. Sheintuch, On-site pure hydrogen production by methane steam reforming in high flux membrane reactor: Experimental validation, model predictions and membrane inhibition. Chemical Engineering Journal. 262 (2015) 862-874.

[45]. H. Roh, D. Lee, K. Koo, U. Jung, W. Yoon, Natural gas steam reforming for hydrogen production overmetal monolith catalyst with efficient heat-transfer. Int. J. Hydrogen Energy. 35 (2010) 1613-1619.

[46]. L. Sang, B. Sun, H. Tan, C. Du,Y. Wu, C. Ma, Catalytic reforming of methane with $\mathrm{CO}_{2}$ over metal foambased monolithic catalysts. Int. J. Hydrogen Energy 37 (2012) 13037-13043.

[47]. F. Gallucci, L. Paturzo, A. Basile, A simulation study of steam reforming of methane in a dense tubular membrane reactor. Int J Hydrogen Energy. 29 (2004) 611-7.

[48]. J. Oklany, K. Hou, R. Hughes, A simulative comparison of dense and microporous membrane reactors for the steam reforming of methane. Appl. Catal. A Gen. 170 (1998) 13-22.

[49]. M. De Falco, L. Di Paola, L. Marrelli, P. Nardella, Simulations of large-scale membrane reformers by a twodimensional model. Chem. Eng. J. 128 (2-3) (2007) 115-25. [50]. K.S. Patel, A.K. Sunol, Modeling and simulation of methane steam reforming in a thermally coupled membrane reactor. International Journal of Hydrogen Energy. 32 (2007) 2344-58.

[51]. G. Marigliano, G. Barbieri, E. Drioli, Effect of energy transport on a palladium-based membrane reactor for methane steam reforming process. Catal Today. 67 (2001) 85-99.

[52]. F.A.N. Fernandes, A.B. Soares Jr, Methane steam reforming modeling in a palladium membrane reactor.Fuel. 85 (2006) 569-573.

[53]. M.E. Adrover, E. Lopez, D.O. Borio, M.N. Pedernera, Theoretical study of a membrane reactor for the water gas shift reaction under nonisothermal conditions. A.I.Ch.E. J. 55 (12) (2009) 3206-3213.

[54]. A. Caravella, F.P. Di Maio, A. Di Renzo, Optimization of membrane area and catalyst distribution in a permeativestage membrane reactor for methane steam reforming. Journal of Membrane Science. 321 (2008) 20921.

[55]. J. Huppmeier, M. Baune, J. Thoming, Interactions between reaction kinetics in ATR-reactors and transport mechanisms in functional ceramic membranes: a simulation approach. Chemical Engineering Journal. 142 (2008) 225-38 [56]. Z.B. Rui, K. Zhang, Y.D. Li, Y.S. Lin, Simulation of methane conversion to syngas in a membrane reactor: Part I A model including product oxidation. International Journal of Hydrogen Energy. 33 (2008) 2246-53.

[57]. K. Gosiewski, K. Warmuzinski, M. Tanczyk, Mathematical simulation of WGS membrane reactor for gas from coal gasification. Catalysis Today. 156 (2010) 229-36.
[58]. D.S.A. Simakov, M. Sheintuch, Model-based optimization of hydrogen generation by methane steam reforming in auto-thermal packed-bed membrane reformer. AIChE Journal. 57 (2011) 525-41.

[59]. M.E. Ayturk, N.K. Kazantzis, Y.H. Ma, Modeling and performance assessment of Pd- and $\mathrm{Pd} / \mathrm{Au}$-based catalytic membrane reactors for hydrogen production. Energy and Environmental Science. 2 (2009) 430-8.

[60]. N.S. Abo-Ghander, J.R. Grace, S.S.E.H. Elnashaie, C. Jim Lim, Modelling of a novel membrane reactor to integrate dehydrogenation of ethylbenzene to styrene with hydrogenation of nitrobenzene to aniline. Chem. Eng. Sci. 63 (2008) 1817-1826.

[61]. S.T. Oyama, P. Hacarlioglu The boundary between simple and complex descriptions of membrane reactors: the transition between 1-D and 2-D analysis. Journal of Membrane Science. 337 (2009) 188-99.

[62]. T.P. Tiemersma, C.S. Patil, M.V. Annaland, J.A.M Kuipers, Modelling of packed bed membrane reactors for auto-thermal production of ultrapure hydrogen. Chemical Engineering Science. 61 (2006) 1602-16.

[63]. J. Xuan, M.K.H. Leun, D.Y.C. Leung, M. Ni. Integrating chemical kinetics with CFD modeling for autothermal reforming of biogas. International Journal of Hydrogen Energy. 34 (2009) 9076-86.

[64]. M.E.E. Abashar, A.A. Al-Rabiah, Production of ethylene and cyclohexane in a catalytic membrane reactor, Chem. Eng. Proc. 44 (2005) 1188-1196.

[65]. P. Marin, Y. Patino, F.V. Diez, S. Ordonez, Modelling of hydrogen perm-selective membrane reactors for catalytic methane steam reforming. International journal of hydrogen energy. 37 (2012) 18433-18445.

[66]. R.J. Byron Smith, L. Muruganandam, S. Murthy Shekhar. CFD analysis of water gas shift membrane reactor. Chemical Engineering Research and Design. 89 (2011) 2448-56.

[67]. A. Caravella, F.P. Di Maio, A. Di Renzo. Optimization of membrane area and catalyst distribution in a permeativestage membrane reactor for methane steam reforming. Journal of Membrane Science. 321 (2008) 20921.

[68]. S.T. Oyama, P. Hacarlioglu. The boundary between simple and complex descriptions of membrane reactors: the transition between 1-D and 2-D analysis. Journal of Membrane Science. 337 (2009) 188-99.

[69]. N.C. Markatos, E. Vogiatzis, M.K. Koukou, N. Papayannakos, Membrane reactor modelling-a comparative study to evaluate the role of combined mass and heat dispersion in large-scale adiabatic membrane modules. Chem. Eng. Res. Des. 83 (A10) (2005) 11711178.

[70]. M.V. Twigg, J.T. Richardson, Fundamentals and applications of structured ceramic foam catalysts. IndEngChem Res. 46(12) (2007) 4166-77.

[71]. J. Xu, G.F. Froment, Methane steam reforming, methanation and water-gas shift: Intrinsic Kinetics. AlChE Journal. 35(1) (1989) 88-96.

[72].B.A. Finlayson, Nonlinear analysis in chemical engineering, McGraw-Hill (1980) 60-171.

[73].G. Barbieri, A. Brunetti, G. Tricoli, E. Drioli, An innovative configuration of a $\mathrm{Pd}$-based membrane reactor 
for the production of pure hydrogen. Experimental analysis of water gas shift. J. PowerSources. 182 (2008) 160-167.

[74]. D. Edouard, M. Lacroix, P.C. Huu, F. Luck,Pressure drop modeling on SOLID foam: State-of-the art correlation. Chemical Engineering Journal. 144 (2008) 299-311.

[75]. J. Shu, B.P.A. Grandjean, S. Kaliaguine, Methane steam reforming in asymmetric $\mathrm{Pd}-$ and $\mathrm{Pd}-\mathrm{Ag}$ /porous SS membrane reactors. Appl. Catal. A. 119 (1994) 305-325.

[76]. Y. Lin, Y.M. Liu, S.L. Chuanga, C.H. Chub, Effect of incipient removal of hydrogen through palladium membrane on the conversion of methane steam reforming: experimental and modeling. Catalysis Today. 82 (2003) 127-139.

[77]. A.S. Kyriakides, L. Rodrıguez-Garcıa, S. Voutetakis, D. Ipsakis, P. Seferlis, S. Papadopoulou, Enhancement of pure hydrogen production through the use of a membrane reactor. International Journal of Hydrogen Energy. 39 (2014) 4749-4760

[78]. J.M.V. Castillo, T. Sato, N. Itoh, Effect of temperature and pressure on hydrogen production from steam reforming of biogas with $\mathrm{Pd}-\mathrm{Ag}$ membrane reactor. International journal of hydrogen energy. 40 (2015) 3582-3591.

[79]. P. Khayargoli1, V. Loya, L. P. Lefebvre and M. Medraj, The impact of microstructure on the permeability of metal foams. CSME 2004 220-228.

[80]. A. Bhattacharya, V.V. Calmidi, R.L. Mahajan, Thermophysical properties of high porosity metal foams. Int J Heat Mass Transf. 45 (2002) 1017-1031.

[81]. K. Boomsma, D. Poulikakos, The effect of compression and pore size variations on the liquid flow characteristics in metal foams. ASME J Fluids Eng. 124 (2002) 263-272.

[82]. J.T. Richardson, Y. Peng, et al., Properties of ceramic foam catalyst supports: pressure drop. Applied Catalysis A: General. 204 (1) (2000) 19-32.

[83].J.W. Paek, B.H. Kang, S.Y. Kim, J.M. Hyun, Effective Thermal Conductivity and Permeability of Aluminum Foam Materials. Int. J. of Thermophysics. 21(2) 2000.

[84]. C. Beckermann, R. Viskanta, Forced convection boundary layer flow and heat transfer along a flat plate embedded in a porous medium, Int. J. of Heat and Mass Transfer. 30 (1986) 1547-1551.

[85]. G.P.J. Diedericks and J.P. du Plessis, Electrical conduction and formation factor in isotropic porous media, Advances in Water Resources. 19 (4) (1996) 225-239.

[86]. B.V. Antohe, J.L. Lage, D.C. Price, R.M. Weber, Experimental Determination of Permeability and Inertia Coefficients of Mechanically Compressed Aluminum Porous Matrices. J. of Fluids Engineering.119 (1997) 405412.

\section{BIOGRAPHIES}

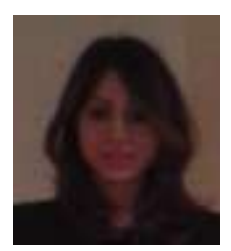

Grazia Leonzio is a $\mathrm{PhD}$ student at Department of Industrial and Information Engineering and Economics, University of L'Aquila, Via Giovanni Gronchi 18, 67100 L'Aquila, Italy; e-mail: grazia.leonzio@graduate.univaq.it; 